Annals of Warsaw University of Life Sciences - SGGW

Land Reclamation No 48 (1), 2016: 41-52

(Ann. Warsaw Univ. Life Sci. - SGGW, Land Reclam. 48 (1), 2016)

\title{
Landfill liners from dam reservoir sediments
}

\author{
KAROLINA KOŚ, EUGENIUSZ ZAWISZA \\ Department of Hydraulic Engineering and Geotechnics \\ University of Agriculture in Krakow
}

\begin{abstract}
Landfill liners from dam reservoir sediments. Every municipal solid waste landfill has to be properly secured to protect the natural environment from possible leachate. Most often an artificial sealing is used, which is based on a soil liner from cohesive soils (clays, silts). Usability evaluation of bottom sediments from Rzeszowski Reservoir for building these liners was presented in the paper. Sediments from dam reservoirs, gathered as a result of the siltation process, can be a valuable material for earthworks purposes. Determination of their possible ways of usage is important, especially before the planned dredging, because thanks to that this material will not be put on a heap. Based on the analysis of the geotechnical parameters of these sediments it was stated that this material can be preliminary allowed for using in liners.
\end{abstract}

Key words: landfill liners, dam reservoirs, bottom sediments

\section{INTRODUCTION}

Landfills are constructions which commonly occur in the waste management infrastructure. At the same time they are believed to be the biggest threat to the natural environment, especially ground water and soil (Obidoska and Jasińska 2008). Because of the nuisance or even threat to the environment the main requirement for a landfill construction is to limit or, if it is possible, entirely prevent its negative influence on the natu- ral environment (Choma-Moryl 2004). Municipal solid waste landfill can be regarded as safe for the groundwater and soil natural environment if one of the following conditions is fulfilled (Garbulewski 2000): the landfill is located in the area, where there is a natural geological barrier or the bottom and slopes of the landfill are properly sealed. The most advantageous situation is the first one there is a geological barrier that is wider than the designed landfill. Despite that an artificial barriers are usually used for a number of reasons: it is difficult to find a natural layer of soil which is homogeneous, impermeable, without cracks or interbeddings of permeable soils. There are also many other factors that have to be taken into consideration, for example residents' protests, occurring of areas where there are underground reservoirs, karst, landslides, steep slopes (above $\left.10^{\circ}\right)$, mining damages or fertile soils. That is the reason why, despite favorable geological conditions, the landfill must be located elsewhere and the artificial liner must be used.

The artificial liner is a multi-layered sealing system, its base is a mineral layer made form a compacted cohesive soil 
and different types of geotextiles, mainly goemembranes (Fig. 1). The main function of the mineral layer is to reduce pollution migration and delay their spreading in the environment. Additionally, the sealing layer should have a proper swelling and shrinking characteristics, a proper load capacity and not undergo deformations (Choma-Moryl 2004). Therefore a liner should have a low permeability, high adsorption, resistance sediments from water reservoirs can be used to form the sealing liner.

\section{MATERIAL AND METHODS}

The tests were carried out on bottom sediments from Rzeszowski Reservoir (southern Poland). The reservoir was built in 1973, mainly in order to ensure proper functioning of water intakes and flood protection. The capacity of the reservoir was initially 1.8 million $\mathrm{m}^{3}$

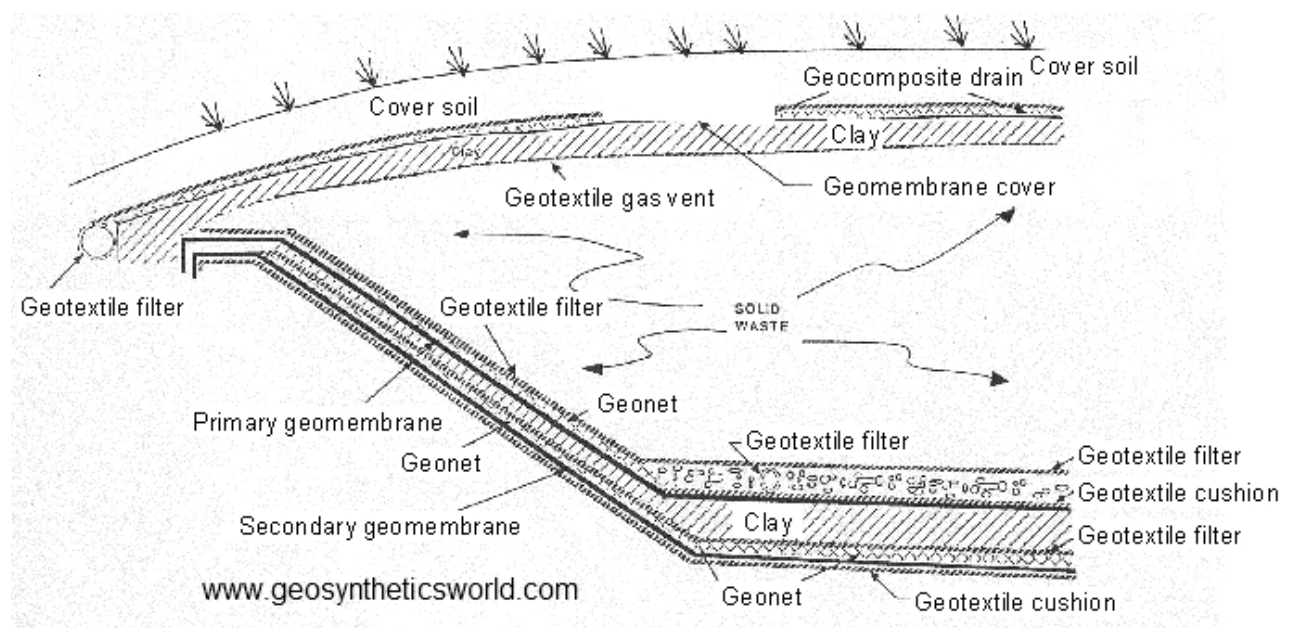

FIGURE 1. Landfill construction (www.geosyntheticsworld.com)

to erosion and different chemicals and it should be deformable because of the possibility of non-uniform settlement. Soil liners, geomembranes and bentonite liners are used for sealing the landfill bottom, but the most effective protection is still a liner made from fine-grained soils, like clays (Nowakowska and Garbulewski 2011). Instead of natural soils, whose resources are exhaustible, bottom and the surface area of 68.2 ha (www. krakow.rzgw.gov.pl). The siltation process was very intense in case of this reservoir. Currently up to $60 \%$ of its original capacity is filled with sediments, so it no longer fulfils all the functions for which it was built. It is estimated that about 1.5 million $\mathrm{m}^{3}$ of sediments can be dredged from the reservoir (www.tvp.pl/ rzeszow) as a result of dredging. It is usually impossible to work on a completely 
empty reservoir and use basic earthworks machinery, so cutter or suction dredgers are used. A pulp of sediments and water, which is transported to the shore, must be dried before using. Dewatering can be carried out in geotextile tubes (Fig. 2), they are filled with the pulp and after the process is done they are cut open and the material is ready to use. Dredged material can be deposited on a heap or used, which can be ecologically and economically beneficial. tent was determine using $30 \%$ solution of hydrogen peroxide. Falling-head permeability tests with consolidometer were carried out under the load of $12.5 \mathrm{kPa}$. The specimens were $7.5 \mathrm{~cm}$ in diameter and $1.9 \mathrm{~cm}$ high, they were compacted at the optimal moisture content and the compaction index of $I_{s} \approx 1.00$. Liquid limit was determined in cone penetrometer and plastic limit by rolling threads. Specific surface area was determined using methylene blue absorption method. Cal-

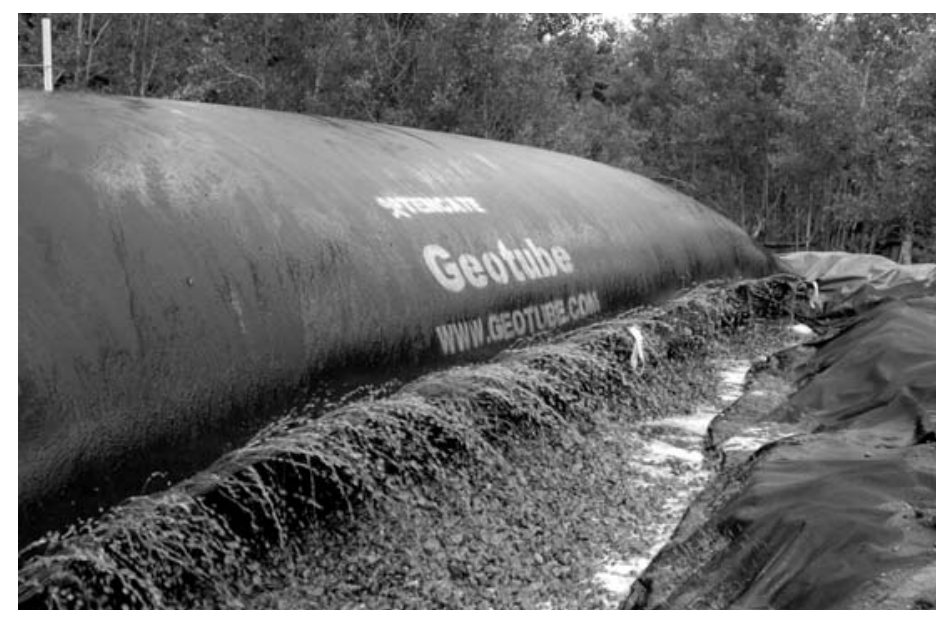

FIGURE 2. Dewatering tube (www.geotube.com)

Samples of sediments were taken from different parts of the reservoir and then mixed in order to obtain the average sample. Determining of the basic parameters was carried out using standard methods (PN-EN-ISO TS 17892:2009). Optimal moisture content and maximum dry density were determined using Standard Proctor Tests (compaction energy of $0.59 \mathrm{~J} \cdot \mathrm{cm}^{-3}$ ). Organic matter con- cium carbonate content was determined using Scheibler's method, according to PN-ISO 10693:2002.

Shear strength tests were carried out in standard direct shear box apparatus in boxes that were $60 \times 60 \mathrm{~mm}$ in cross section. Samples that were $1.75 \mathrm{~cm}$ high, were formed at the optimum water content and compaction index $I_{s}=0.95$. Samples were loaded with 50,100 and $200 \mathrm{kPa}$ and then sheared until $10 \%$ of horizon- 
tal deformation was obtained. Strength parameters were calculated for the maximum values of shear stress $\left(\max \tau_{f}\right)$ using the method of least squares.

The compressibility was determined using oedometer on samples that were $7.5 \mathrm{~cm}$ in diameter and $1.9 \mathrm{~cm}$ high. The samples were formed directly in the ring of the apparatus, at moisture content close to optimal and compaction index of $I_{s}=0.95$. Increments of vertical static load of 12.5, 25, 50, 100, 200 and $400 \mathrm{kPa}$ were applied to the samples. Each load level was applied until the full consolidation was reached.

\section{RESULTS AND DISCUSSION}

The sediments from Rzeszowski Reservoir were classified as silt, the uniformity coefficient was over 13 (Table 1). Organic matter content was over 3\% so the sediments were classified as loworganic. Optimal water content was almost $25 \%$ and the maximum dry density $-1.45 \mathrm{~g} \cdot \mathrm{cm}^{-3}$. The permeability was low, the coefficient decreased from $1 \cdot 10^{-8}$ to about $1 \cdot 10^{-9} \mathrm{~m} \cdot \mathrm{s}^{-1}$ along with the increase in compaction index from 0.90 to 1.00 . The specific surface area was low and equalled over $52 \mathrm{~g} \cdot \mathrm{cm}^{-3}$. Low value of the specific area is the result of relatively low clay fraction content, because mainly clay minerals, as a basic component of the sorption complex, influence the sorption capacity and the surface area. Calcium carbonate content was only $4.7 \%$. Liquid limit was about $41 \%$ and the plasticity index was close
TABLE 1. Geotechnical parameters of the bottom sediments

\begin{tabular}{|c|c|}
\hline Parameter & Value \\
\hline $\begin{array}{l}\text { Fraction content }[\%] \\
\text { sand, } \mathrm{Sa}(2-0.063 \mathrm{~mm}) \\
\text { silt, } \mathrm{Si}(0.063-0.002 \mathrm{~mm}) \\
\text { clay, } \mathrm{Cl}(<0.002 \mathrm{~mm})\end{array}$ & $\begin{array}{c}8.5 \\
83.0 \\
8.5\end{array}$ \\
\hline $\begin{array}{l}\text { Name acc. to } \\
\text { PN-EN ISO 14688-2:2004 }\end{array}$ & $\mathrm{Si}$ (silt) \\
\hline Uniformity coefficient, $C_{u}[-]$ & 13.3 \\
\hline Specific density, $\rho_{s}\left[\mathrm{~g} \cdot \mathrm{cm}^{-3}\right]$ & 2.53 \\
\hline Ignition loss [\%] & 4.67 \\
\hline Organic matter content $[\%]$ & 3.33 \\
\hline Optimal water content [\%] & 24.8 \\
\hline Maximum dry density $\left[\mathrm{g} \cdot \mathrm{cm}^{-3}\right]$ & 1.445 \\
\hline Liquid limit [\%] & 40.6 \\
\hline Plasticity limit [\%] & 26.8 \\
\hline Plasticity index [\%] & 13.8 \\
\hline $\begin{aligned} \text { Permeability coefficient }\left[\mathrm{m} \cdot \mathrm{s}^{-1}\right] \text { at: } & \\
I_{s} & =0.90 \\
I_{s} & =1.00\end{aligned}$ & $\begin{array}{l}1.05 \cdot 10^{-8} \\
1.12 \cdot 10^{-9}\end{array}$ \\
\hline Specific surface area $\left[\mathrm{m}^{2} \cdot \mathrm{g}^{-1}\right]$ & 52.44 \\
\hline pH reaction $[-]$ & 7.30 \\
\hline Calcium carbonate content $[\%]$ & 4.68 \\
\hline Swelling index [\%] & 26.0 \\
\hline Angle of internal friction, $\varphi\left[^{\circ}\right]$ & 22.3 \\
\hline Cohesion, $c[\mathrm{kPa}]$ & 42.7 \\
\hline $\begin{array}{l}\text { Oedometric modulus [MPa] of: } \\
\text { primary compression } \\
\text { secondary compression }\end{array}$ & $\begin{array}{c}3.9 \\
18.6\end{array}$ \\
\hline
\end{tabular}

to $14 \%$. Skempton's activity, also defined as activity index $\left(I_{a}\right)$, was 1.6 , so the value was high in relation to the values typical for mineral soils, which are in range of 0.75-1.25 (Myślińska 1998). 
Swelling index was $26 \%$ so it was a relatively high value considering that the clay fraction content was only over $8 \%$. At optimal moisture content and high compaction level $\left(I_{s}=1.00\right)$ the sediments had relatively high values of shear strength parameters - the angle of internal friction was over $22^{\circ}$ and cohesion was almost $43 \mathrm{kPa}$. The tested material had high compressibility, the primary oedometric modulus was almost $4 \mathrm{MPa}$. Although the secondary compression modulus was much higher - 18.6 MPa.

Usability evaluation for soil liners in municipal solid waste landfills was carried out by comparing the values obtained from laboratory tests with the corresponding criteria values, that can be found in standards, norms and publications (Table 2). The primary purpose of the liner system is to isolate the landfill contents from the environment and, therefore, to protect the soil and ground water from pollution originating in the landfill (Hughes et al. 2008). Thus, the most important function of the soil liner is to make it impossible for leachate to migrate out of the landfill and for rainfall to infiltrate into the landfill. That is the reason why the permeability criterion is defined as the basic one. It is the only criterion which is given by the corresponding Polish Regulation of the Minister of Environment on landfills from 2013, which defines the required permeability coefficient value for the artificial mineral barrier to be equal or less than $1 \cdot 10^{-9} \mathrm{~m} \cdot \mathrm{s}^{-1}$ (it also defines its mini- mum thickness $-0.5 \mathrm{~m}$ ). The permeability coefficient of the bottom sediments was $1.12 \cdot 10^{-9} \mathrm{~m} \cdot \mathrm{s}^{-1}$ at the compaction index $I_{s}=1.00$, so it can be said that the criterion is fulfilled.

Agranulationcriteriondefines fraction contents which (after a proper compaction) will ensure obtaining the required value of the permeability coefficient. The recommendations concern mainly a maximum grain size (because of the possibility of geosynthetics perforation) and a fine fractions content (which will ensure the required properties). According to many different sources it is recommended that the grain size should not be larger than $25-50 \mathrm{~mm}$, fraction less than $0.075 \mathrm{~mm}$, content should be higher than $30-60 \%$ and clay content should be higher than $15-20 \%$ (Table 2). The bottom sediments fulfill the recommendation concerning the maximum grain size and the fine fraction content, but the clay fraction content is too low $(8.5 \%)$. Therefore these sediments do not fulfill the granulation criterion (Figs 3, 4).

Another criterion is characterized by several parameters - linear shrinkage, colloidal activity, swelling pressure and swelling index. The values of these parameters inform about the water influence on the soil behavior. The colloidal activity of useful soils should be above 0.4 , values of the other parameters should ensure the required deformation properties. The swelling and the shrinkage are one of the deformation processes which occur in the clay minerals as the 
TABLE 2. Evaluation of usability of the sediments for soil liners in municipal solid waste landfills

\begin{tabular}{|c|c|c|c|c|c|}
\hline \multirow[b]{2}{*}{ Parameter } & \multicolumn{4}{|c|}{ Requirements according to: } & \multirow[b]{2}{*}{ Bottom sediments } \\
\hline & 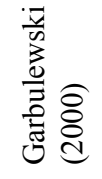 & $\frac{\dot{0}}{\sqrt[\pi]{\pi}}$ & 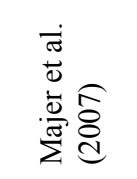 & 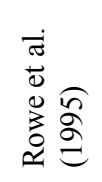 & \\
\hline Clay fraction content $[\%]$ & $\begin{array}{l}\text { acc. to } \\
\text { Fig. } 3\end{array}$ & $>20$ & $\begin{array}{l}\text { acc. to } \\
\text { Fig. } 4\end{array}$ & $15-20$ & 8.5 \\
\hline Fraction $<0.075 \mathrm{~mm}[\%]$ & $>30$ & $>60$ & $\geq 60^{*}$ & - & 95 \\
\hline Maximum grain size $[\mathrm{mm}]$ & $25-50$ & - & - & - & 0.25 \\
\hline Organic matter content [\%] & $<5$ & \multicolumn{2}{|c|}{$\leq 5$} & - & 3.33 \\
\hline $\begin{array}{l}\text { Capacity of methylene blue, } \\
M B C\left[\mathrm{~g} \cdot 100 \mathrm{~g}^{-1}\right]\end{array}$ & - & \multicolumn{2}{|c|}{ any value } & $\geq 10$ & 2.5 \\
\hline Calcium carbonate content $[\%]$ & $<30$ & \multicolumn{2}{|c|}{$\leq 15$} & - & 4.68 \\
\hline Skempton's activity, $I_{a}[-]$ & - & - & $\begin{array}{l}\geq 0.4 \text { (acc. } \\
\text { to Fig. } 5 \text { ) }\end{array}$ & $\geq 0.3$ & 1.62 \\
\hline Liquid limit [\%] & - & $\geq 30$ & \multirow{2}{*}{$\begin{array}{l}\text { acc. to } \\
\text { Fig. } 6\end{array}$} & - & 40.6 \\
\hline Plasticity index [\%] & $>7-10$ & $\geq 15$ & & $>7$ & 13.8 \\
\hline Swelling index [\%] & - & $\geq 5$ & $\geq 4$ & - & 26 \\
\hline Permeability coefficient, $k_{10}\left[\mathrm{~m} \cdot \mathrm{s}^{-1}\right]$ & - & $10^{-10}$ & $\leq 10^{-9}$ & $\begin{array}{l}10^{-9}- \\
-10^{-10}\end{array}$ & $\begin{array}{l}1.05 \cdot 10^{-8} \\
\left(I_{s}=0.90\right) \\
1.12 \cdot 10^{-9} \\
\left(I_{s}=1.00\right)\end{array}$ \\
\hline Angle of internal friction, $\varphi\left[^{\circ}\right]$ & - & - & $\geq 3$ & - & 22.3 \\
\hline Cohesion, c $[\mathrm{kPa}]$ & - & - & $\geq 35$ & - & 42.7 \\
\hline $\begin{array}{l}\text { Oedometric modulus [MPa] of: } \\
\text { primary compression } \\
\text { secondary compression }\end{array}$ & - & - & $\geq 5$ & - & $\begin{array}{c}3.9 \\
18.6\end{array}$ \\
\hline
\end{tabular}

* The sum of clay and silt fractions, ** after Daniel (1991,1993), Brandl (1992), Daniel and Koerner (1995).

effect of an interaction between the minerals and the water that has a different chemical composition (Choma-Moryl 2004). Swelling of the soil can have a positive effect when it comes to the liners, because of their possible self-sealing. The swelling ability is defined by the swelling index and the swelling pressure. The linear shrinkage is determined because of the possibility of dangerous cracks and gaps in the liner. Majer et al. (2007) defined the maximum value of linear shrinkage at $16 \%$. The colloidal activity of the tested sediments was 1.6, according to the nomogram (Fig. 5) sediments can be defined as very active. The tested material fulfills the recommendation about the activity given by both Rowe et al. (1995) and Majer et al. (2007). Similarly in case of the required 


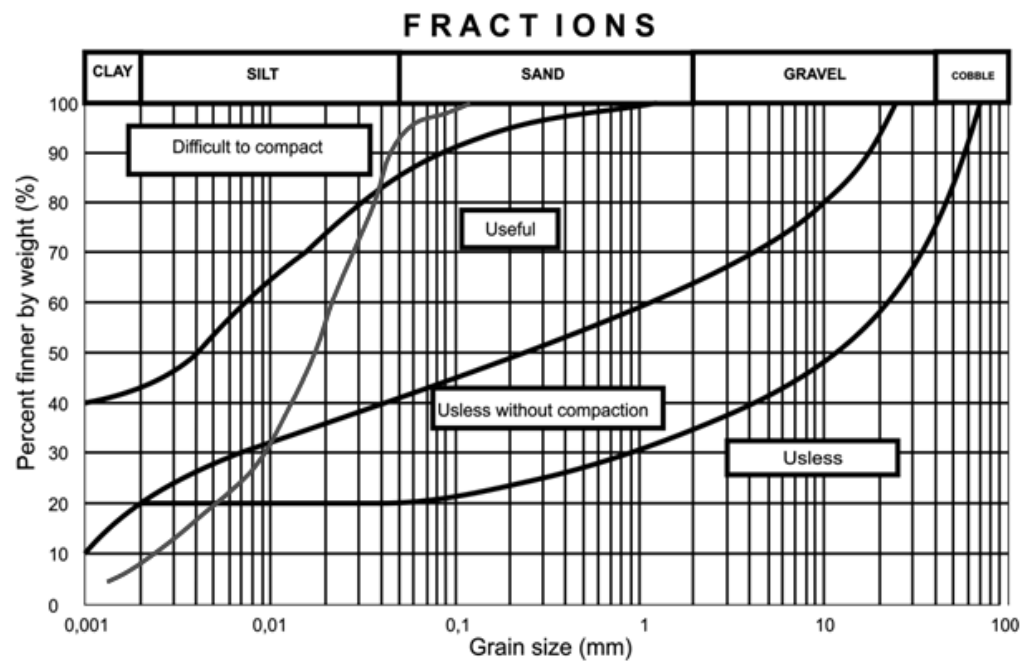

FIGURE 3. Grain size distribution curve of the sediments in relation to the requirements for mineral soil liners (Garbulewski 2000)

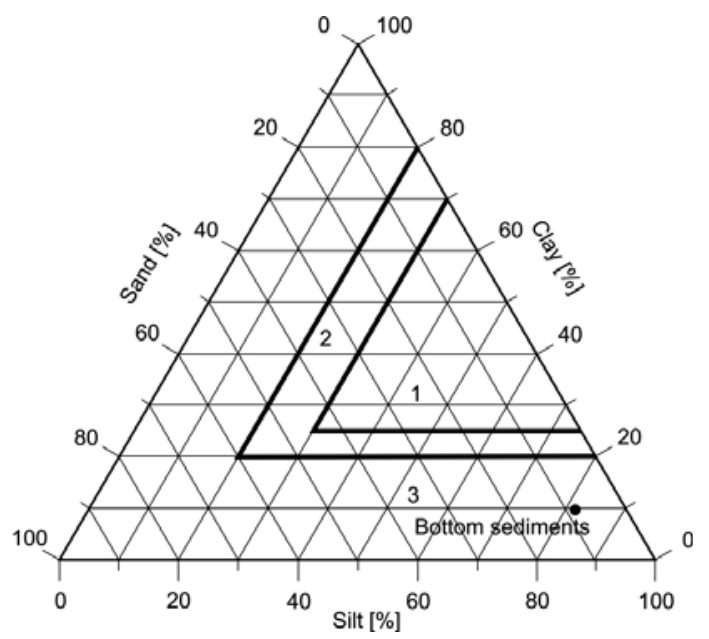

FIGURE 4. Grain size distribution of the sediments in relation to the requirements for mineral soil liners; 1 - very useful, 2 - useful, 3 - useless without improving (Majer et al. 2007)

value of the swelling index - it was $26 \%$ for the bottom sediments and 4 or $5 \%$ was the minimum value.

A mineral criterion defines the minimum content of clay minerals to be $20 \%$ (Majer et al. 2007), but it is also impor- tant to determine their type, because it has an influence on the sorption, the chemical resistance and the ion exchange abilities of the soil. A low clay fraction content in the bottom sediments (and thereby probably low clay minerals con- 


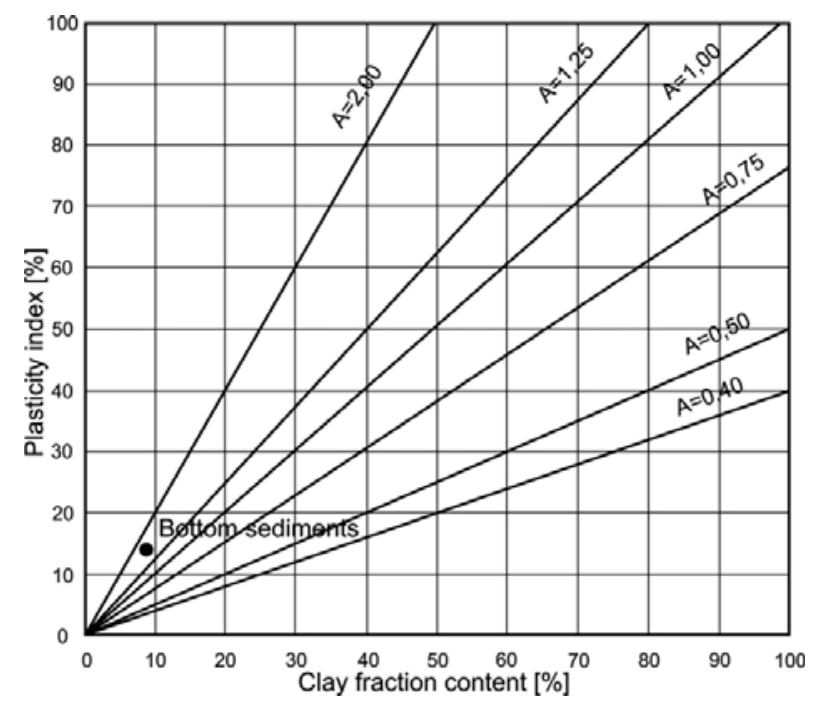

FIGURE 5. Activity nomogram (Majer et al. 2007)

tent) results in a low value of the sorption capacity, which equals $2.5 \mathrm{~g} \cdot 100 \mathrm{~g}^{-1}$ (when the required value is $10 \mathrm{~g}$ ). As an addition to the mineral composition tests a carbonate content and an organic matter content should also be determined. The recommendations concerning both these parameters are fulfilled in case of the tested sediments - the carbonate content was almost $4.7 \%$ whereas the maximum allowable value is 15 or $30 \%$ (according to different sources - see Table 1) and the organic matter content was over $3.3 \%$, so it was lower than the maximum $5 \%$.

A plasticity criterion concerns the technical aspect of the construction of the mineral liner. The soils that have a proper plasticity index are easy to form and at the same time a low value of the permeability coefficient (below $10^{-9} \mathrm{~m} \cdot \mathrm{s}^{-1}$ ) can be obtained. Research showed that the soils that are easily formed and have the best permeability properties are the ones whose plasticity index is from 7 to $30 \%$ (Gwóźdź 2007). In case of soils that have a low plasticity index it is difficult to obtain the required permeability, whereas soils with high values of this parameter are difficult to form. Additionally, it is important to determine the range of the moisture content when the soil is in the plastic state, because only then it is possible to form an impermeable liner, without any cracks and defects (Choma-Moryl 2004). In the solid state the soil would create a layer of crumbled lumps, which could not ensure the required permeability and in the liquid state the soil could not be a stable ground for the landfill. General recommendations concerning plasticity index (from 7 to $30 \%$ ) are 
fulfilled in case of the tested sediments. Although, according to the nomogram (Fig. 6), where the liquid limit is also taken into consideration, the sediments are outside of the area of useful soils.
The soil liners should be deformable, because they have to transmit non-uniform settlements. The minimal value of compression modulus is $5 \mathrm{MPa}$. The primary compression modulus of the

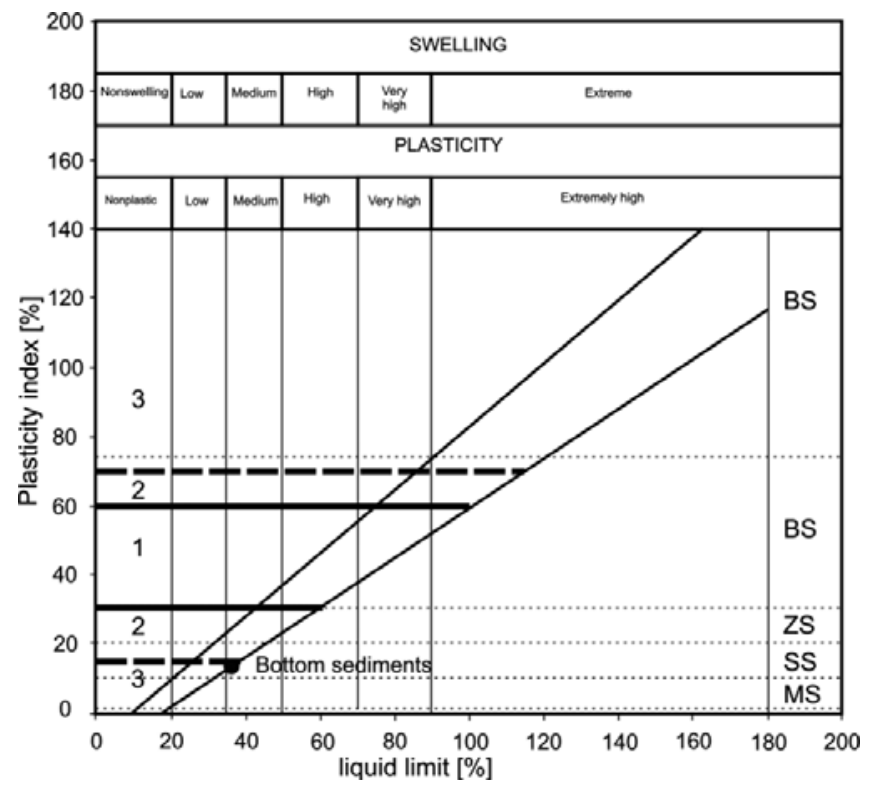

FIGURE 6. Plasticity nomogram: 1 - very useful, 2 - useful, 3 - useless without improving (Majer et al. 2007)

Another criterion that should be taken into account while designing the landfill construction is a strength criterion. It defines the minimal values of the angle of internal friction $\left(3^{\circ}\right)$ and the cohesion $(35 \mathrm{kPa})$. This criterion is especially important in case of the liners designed on the slope, where a proper strength has to ensure the stability of the construction. The values of the angle of internal friction and cohesion of the bottom sediments are higher than the required ones, so it can be stated that the strength criterion is fulfilled. bottom sediments was almost $4 \mathrm{MPa}$, so this material is susceptible to deformations, although a high value of the secondary compression modulus (beyond $18 \mathrm{MPa}$ ) allows predicting a proper compression strength.

According to the Building Research Institute in Poland soils can be evaluated for using in municipal solid waste landfills mineral liners using a nomogram (Fig. 7). It is based on the permeability coefficient and a number of points, which are based on the values of a several im- 


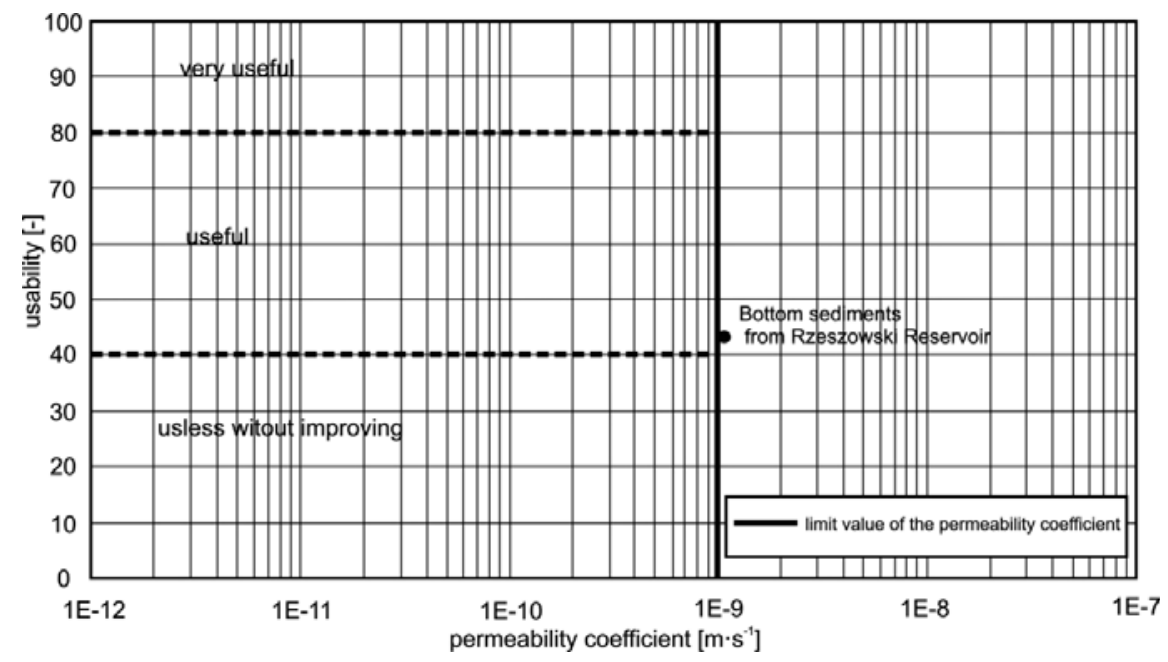

FIGURE 7. Nomogram for usability evaluation for mineral liners in municipal solid waste landfills (Majer et al. 2007)

portant parameters, like the clay fraction content, the plasticity index, the liquid limit, the linear shrinkage and more (Majer et al. 2007). Tested sediments have the required number of points -42 , but the value of permeability coefficient is close to the limit value.

\section{CONCLUSIONS}

It should be emphasized that there are differences in the criteria values that are given by different authors for the evaluation of soil usability for liners in municipal solid waste landfills. Thus it can be stated that during the evaluation of a given soil for a liner a total of their parameters - both physical and mechanical - should be taken into consideration and based on them a decision concerning its usage should be made. In consideration of the above it can be stated that the bottom sediments from Rzeszowski Reservoir can be used for the liners in Municipal Solid Waste Landfills. Recommendations concerning maximum grain size, fine fraction content, colloidal activity, swelling, carbonate and organic matter content, plasticity index as well as shear strength are fulfilled. Although increase in the clay fraction content and thus lowering of the permeability coefficient is highly recommended. The permeability coefficient was close to the required value only at a very high compaction. Low clay fraction content influenced not only the granulation criterion, but also the mineral one and both of these criteria are not fulfilled. One way of improving these parameters is bentonite addition, which would significantly lower permeability, but it might not be economically justified. 


\section{REFERENCES}

BRANDL H. 1992: Mineral liners for hazardous waste containment. Geotechnique 42, 1, 57-65.

CHOMA-MORYL K. 2004: Badania wybranych gruntów spoistych z terenu Dolnego Śląska jako uszczelnień składowisk odpadów komunalnych [Evaluation of chosen cohesive clays from Lower Silesia as mineral liners for municipal landfills]. Wydawnictwo Uniwersytetu Wrocławskiego, Wrocław [Engl. summ.].

DANIEL D.E. 1991: Compacted clay and geosynthetic clay linings. Proceedings of the XV CGT Coferenze di Geotecnica di Torina.

DANIEL D.E. 1993: Clay liners. In: Geotechnical practice for waste disposal. D.E. Daniel (Ed.) Chapman and Hall, London.

DANIEL D.E., KOERNER R.M. 1995: Waste containment facilities: guidance for construction, quality assurance and quality control of liner and cover systems. Asce Press, American Society of Civil Engineers, New York.

GARBULEWSKI K. 2000: Dobór i badania gruntowych uszczelnień składowisk odpadów komunalnych [Selection and testing of liners in Municipal Solid Waste Landfills]. Wydawnictwo SGGW, Warszawa (Engl. summ.).

GWÓŹDŹ R. 2007: Właściwości osadów spoistych Jeziora Rożnowskiego w aspekcie ich geotechnicznego wykorzystania [Properties of cohesive sediments from Rożnowski Reservoir in the aspect of their geotechnical usage]. Doctoral thesis. Politechnika Krakowska, Kraków.

HUGHES K., CHRISTY A., HEIMLICH J. 2008: Landfill Types and Liner Systems. Ohio State University Extension Fact Sheet CDFS-138-05. Available online: http://ohioline.osu.edu.

Rozporządzenie Ministra Środowiska $\mathrm{z}$ dnia 30 kwietnia 2013 r. w sprawie składowisk odpadów, Dz.U. 2013 nr 39, poz. 320 [Regulation of the Minister of Environment from 30 February 2013 on landfills].

MAJER E. 2005: Ocena właściwości przesłonowych iłów do budowy składowisk odpadów. [Usability evaluation of clays for landfill con- struction]. Doctoral thesis. ITB, Warszawa (Engl. summ.).

MAJER E., ŁUCZAK-WILAMOWSKA B., WYSOKIŃSKI L., DRĄGOWSKI A. 2007: Zasady oceny przydatności gruntów spoistych Polski do budowy mineralnych barier izolacyjnych. [Rules for usability evaluation of cohesive soils for mineral liners]. ITB, Warszawa.

MYŚLIŃSKA E. 1998: Laboratory tests on soils. Wydawnictwo Naukowe PWN, Warszawa.

NOWAKOWSKA M., GARBULEWSKI K. 2011: Mieszanka iłu i węgla aktywnego jako materiał do uszczelniania składowisk odpadów [Clay-activated carbon blend as a material to liner of landfill]. Przeglad Naukowy - Inżynieria i Ksztaltowanie Środowiska 54, 275-284 (Engl. summ.).

OBIDOSKA G., JASIŃSKA D. 2008: Phytotoxicity and potential genotoxicity of Radiowo municipal landfill leachate. Ann. Warsaw Univ. of Life Sci. - SGGW, Land Reclam. 40, 39-44. PN-ISO 10693:2002. Soil quality - Calcium carbonate content test.

PN-EN-ISO 14688:2004. Geotechnical tests. Soil classification.

PN-EN-ISO TS 17892:2009. Geotechnical tests. Laboratory tests on soils.

ROWE R.K., BOOKER J.R., QUIGLEY R.M. 1995: Clayey barrier systems for waste disposal facilities. E\&FN Spon (Chapman \& Hall), London.

Streszczenie: Uszczelnienia sktadowisk odpadów komunalnych z osadów dennych zbiorników zaporowych. Każde projektowane składowisko odpadów komunalnych wymaga odpowiedniego uszczelnienia, w przypadku sztucznych barier filtracyjnych jednym $z$ elementów jest przesłona wykonana $\mathrm{z}$ gruntów spoistych (gliny, iły). $\mathrm{W}$ pracy przedstawiono ocenę przydatności osadów dennych Zbiornika Rzeszowskiego do budowy wspomnianych przesłon. Osady zbiorników zaporowych, nagromadzone $\mathrm{w}$ wyniku procesu zamulania, mogą stanowić wartościowy materiał do celów budownictwa ziemnego. Określenie możliwości ich wykorzystania jest istotne 
w przypadku planowanego odmulania, dzięki czemu osady nie zostaną złożone na hałdę. $\mathrm{Na}$ podstawie analizy parametrów geotechnicznych osadów dennych w odniesieniu do wielu wartości kryterialnych stwierdzono, że wstępnie można dopuścić osady do formowania przesłon uszczelniających w składowiskach odpadów komunalnych.

Słowa kluczowe: uszczelnienia składowisk odpadów, zbiorniki zaporowe, osady denne
MS. received February 2016

Authors' address:

Karolina Koś, Eugeniusz Zawisza

Uniwersytet Rolniczy w Krakowie

Wydział Inżynierii Środowiska i Geodezji

Mickiewicza 24/28, 30-059 Kraków

Poland

e-mail: karolinasudyka@wp.pl 